\title{
MOKINIŲ SPORTAVIMO IR FIZINIO AKTYVUMO LAISVALAIKIU SĄSAJOS SU PSICHOSOCIALINIAIS, ELGESIO IR MOKYKLOS VEIKSNIAIS
}

\author{
Saulius Šukys, Rasa Jankauskienė \\ Lietuvos kūno kultūros akademija, Kaunas, Lietuva
}

Saulius Šukys. Socialinių mokslų daktaras. Lietuvos kūno kultūros akademijos Kinantropologijos ir sporto raidos katedros lektorius, Socialinių kūno kultūros ir sporto tyrimų laboratorijos vyresnysis mokslo darbuotojas. Mokslinių tyrimų kryptis — sportinės veiklos itaka vaiku ir paauglių elgesiui.

\section{SANTRAUKA}

Mokslineje literatūroje pasigendama darbu, kuriuose analizuojant mokiniu psichosocialinès sveikatos ir elgsenos, susijusios su fiziniu aktyvumu, problemas būtu atsižvelgiama ir i fizinio aktyvumo kryptingumq. Todèl siekta tikslo - atskleisti mokiniu sportavimo, fizinio aktyvumo laisvalaikiu sqsajas su psichosocialiniais, elgesio ir mokyklos veiksniais.

Tiriant naudotas apklausos raštu metodas, kuriuo buvo renkami duomenys apie mokiniu socialinę integracija ir izoliacija, savigarba (psichosocialinius veiksnius), žalingus ipročius ir priekabiavima (elgesio veiksnius), mokymosi motyvacija ir požiūri Ł̇ mokykla (su mokykla susijusius veiksnius). Tiriamaja imti sudare reprezentatyvi 1162 šeštu, aštuntu ir vienuoliktu klasiu mokiniu grupè (534 berniukai ir 628 mergaitès), tikimybiniu atsitiktiniu büdu parinkta iš Kauno miesto mokyklu. Daliai mokiniu neatsakius i klausimus apie savo fizini aktyvuma ar netinkamai tai atlikus, galutine tiriamuju imtis (kurios duomenys tiriant analizuojami) sumažèjo iki 919 asmenu.

Apklausos duomenimis, kur kas aukštesnès socialinès integracijos yra laisvalaikiu fiziškai aktyvūs mokiniai, lyginant juos su sportuojančiais ir fiziškai pasyviais bendraamžiais. Analogiškas skirtumas būdingas ir berniukams, tačiau jis nenustatytas tarp mergaičiu. Nerasta skirtumo tarp sportuojančiu, laisvalaikiu fiziškai aktyviu ir pasyviu mokiniu savigarbos.

Rūkymas labiau paplitęs tarp fiziškai pasyviu mokiniu. Sportuojantys mokiniai dažniau rūko nei laisvalaikiu fiziškai aktyvūs bendraamžiai. Tiek tarp mergaičiu, tiek tarp berniuku nustatyta tendencija, kad dažniau rūko laisvalaikiu fiziškai pasyvūs mokiniai, lyginant juos su fiziškai aktyvesniais bendraamžiais. Skirtumas tarp ìvairaus fizinio aktyvumo mokiniu pagal svaigiuju gérimu vartojimq nenustatytas.

Fiziškai aktyvūs mokiniai dažniau isitraukia ị priekabiavima nei sportuojantys ir fiziškai pasyvūs bendraamžiai. Jiems statistiškai reikšmingai büdingesnis priekabiavimas, tačiau reikšmingu sqsaju tarp viktimizacijos ir fizinio aktyvumo nerasta.

Laisvalaikiu fiziškai aktyvių mokiniu mokymosi motyvacija aukštesnè nei sportuojančiu ir fiziškai pasyviu. Analogiškai laisvalaikiu fiziškai aktyviu berniuku mokymosi motyvacija aukštesnè nei sportuojančiu mokiniu. Laisvalaikiu fiziškai aktyvūs mokiniai yra palankesnès nuomonès apie save, kaip apie moksleivi, nei sportuojantys ar fiziškai pasyvūs bendraamžiai. Analogiška tendencija nustatyta ir tarp mergaičiu, tačiau nebūdinga berniukams.

Raktažodžiai: mokiniu fizinis aktyvumas, socialine integracija ir izoliacija, savigarba, žalingu ipročiu ir priekabiavimo raiška, mokymosi motyvacija, požiūris i mokykla.

\section{IVADAS}

$\mathrm{M}$ okslinèje literatūroje randame nemažai tyrimų, kuriuose pateikiami duomenys apie mokinių psichosocialinès sveikatos, prosocialaus ir problemiško elgesio sąsajas su fiziniu aktyvumu. Tiek užsienio šalių, tiek Lietuvos mokslininkų atliktų tyrimų analizé leidžia teigti, kad egzistuoja teigiama sasaja tarp sportavimo ir savigarbos (Batutis, Kardelis, 2002; Kirkcaldy et al., 2002). Prieštaringesni tyrimų duomenys apie fizinio aktyvumo sąsajas su žalingais ipročiais. Tiek užsienio (Kirkcaldy et al., 2002; Harrison, Narayan, 2003), tiek Lietuvos tyrejjų (Grinienè, 1998; Kardelis ir kt., 2001) duomenimis, sportinė ir kita fiziškai aktyvi veikla yra neigiamai susijusi su rūkymu. Tačiau atsakyti į klausimą apie svaigiuju gėrimu vartojimo ir sportavimo sąajas yra sudėtingiau. Užsienio tyrèjų darbais (Pate et al., 2000; Harrison, Narayan, 2003) nustatytas 
didesnis sportuojančiujų polinkis vartoti svaigiuosius gèrimus. Tuo tarpu Lietuvoje atliktu tyrimu duomenys rodo priešingą tendencija, t. y. sportuojantys asmenys mažiau vartoja svaigiuosius gèrimus (Grinienè, 1998; Petkevičienè ir kt., 2002). Analizuojant agresijos raiškos ir fizinio aktyvumo sąsajas, dažnai analizuojama sportininkų, kartu ir sporto aistruolių polinkio i agresyvumą problema. Tačiau vienareikšmiškai teigti, kad sportuojantys asmenys yra agresyvesni, lyginant juos su nesportuojančiais, tyrimų rezultatai neleidžia.

Ieškant mokinių fizinès veiklos ir ịvairių elgesio aspektų sąsajų, pasigendama tyrimų, kuriuose vienu metu būtų analizuojamas ir formalus moksleiviu sportavimas, ir bendrasis fizinis aktyvumas (Fletcher et al., 2003). Toks požiūris, mūsų nuomone, svarbus dèl kelių priežasčių. Nors sporto šakos pratybų lankymas susijęs su fiziniu aktyvumu, tačiau sportinè veikla yra suaugusiuju valdoma veikla, ja siekiama specifinių tikslų. Fizinis aktyvumas laisvalaikiu yra spontaniškesnè veikla. Beje, prie jos priskiriama ne tik mokinių fiziškai aktyvi veikla (pavyzdžiui, žaidimas su draugais, važiavimas dviračiu), bet ir tokia veikla kaip dainavimas, grojimas, tvarkymasis ir pan. Nors ši veikla taip pat gali būti organizuota, tačiau skirtingai nuo sportavimo, suaugusiuju vaidmuo joje yra minimalus arba jo visai nèra, be to, ja siekiama kitų tikslų. Visgi mokslinèje literatūroje pasigendame tyrimu, kuriuose analizuojant mokiniu psichosocialinès sveikatos ir elgesio, susijusio su fiziniu aktyvumu, klausimus būtų atsižvelgiama į fizinès veiklos pobūdị. Todèl tyrimai, norint atskleisti šias sąsajas, lieka aktualūs. Probleminio klausimo formulavimas leido apibrèžti tyrimo objektą, kurio priklausomi kintamieji yra: socialinès integracijos ir izoliacijos, savigarbos (psichosocialiniai veiksniai), žalingu ipročiu ir priekabiavimo raiška (elgesio veiksniai), mokymosi motyvacija ir požiūris í mokyklą (mokyklos veiksniai). Mokinių sportavimas bei fizinis aktyvumas laisvalaikiu pasirinkti kaip nepriklausomi kintamieji, kurie gali veikti priklausomų kintamujų raišką. Todèl šiuo tyrimu siekta tikslo - atskleisti mokiniu sportavimo, fizinio aktyvumo laisvalaikiu sasajas su psichosocialiniais, elgesio ir mokyklos veiksniais.

\section{TYRIMO METODAI IR ORGANIZAVIMAS}

Tiriamieji. Tiriamają imti sudarè reprezentatyvi 1162 mokiniu grupe (534 berniukai ir 628 mergaitès), tikimybiniu atsitiktiniu būdu parinkta iš Kauno miesto mokyklų. Buvo apklausta 302 šeštos, 342 aštuntos, 284 vienuoliktos klasès bendrojo lavinimo mokyklų moksleiviai ir 234 trečios gimnazijos klasės mokiniai.

Tyrimo metodai. Tyrimo metu taikytas apklausos raštu metodas, kuriuo buvo renkami duomenys apie nepriklausomus ir priklausomus tyrimo kintamuosius.

Mokiniu sportavimas buvo nustatomas pateikiant klausimą apie tai, ar jie šiuo metu lanko tam tikros sporto šakos pratybas ilgiau nei šešis ménesius ir ar tai tęsiasi ne trumpiau kaip pusę metų. Atsakymo variantai buvo „taip“ arba „ne“. Fizinis aktyvumas laisvalaikiu buvo nustatomas pagal mokinių nurodomą įvairios fizinès veiklos dažnumą per savaitę. Atsakymo variantai buvo tokie: kasdien, 4-6 kartus per savaitę, 2-3 kartus per savaitę, viena kartą per savaitę ir nẻ karto. Mokinius, pasirinkusius pirmus du atsakymo variantus, priskyrème prie laisvalaikiu fiziškai aktyviu, o trečią - prie fiziškai pasyvių. Beje, mokiniai, nurodę, kad lanko sporto šakos pratybas, buvo priskirti sportuojančių asmenų grupei nepriklausomai nuo jų nurodyto fizinio aktyvumo laisvalaikiu. Kadangi dalis mokinių netiksliai nurodè savo fizini aktyvumą laisvalaikiu (pasirinkdavo kelis atsakymo variantus), o dalis visai jo nenurode, galutinè tiriamuju imtis sumažejo iki 919 asmenų.

Mokinių socialinè integracija ir izoliacija buvo vertinama pagal keletą klausimų apie tai, kaip jie bendrauja su kitais šeimos nariais, draugais, ar jiems lengva susirasti naujų draugų (Zaborskis, 1996; Batutis, Kadelis, 2002). Mokiniai buvo suskirstyti i dvi grupes: turinčių aukštesni ir žemesni socialinès integracijos lygi.

Mokinių savigarba buvo vertinama naudojant M. Rosenberg (1989) savęs vertinimo skalę, kurią sudaro 10 teiginių, parodančiu asmens požiūrị i save, savo vertę ir svarbą. Tiriamieji turējo įvertinti, kiek kiekvienas teiginys atitinka jų požiūri i save, pasirinkdami vieną iš keturiu atsakymo variantų: nuo „visiškai sutinku“ iki „visiškai nesutinku“. Analizuojant savęs vertinimo duomenis, buvo apskaičiuojamas suminis balas. Pagal gautą bendrą visų tiriamujų balų sumos vidurki, suskirsteme juos i dvi grupes: aukštesnès ir žemesnès savigarbos.

Mokinių rūkymas ir svaigiuju gèrimų vartojimas nustatytas pateikiant klausimą apie tai, kaip dažnai per pastaruosius 12 mėnesių jie tai darè. Pagal atsakymus tiriamuosius suskirstėme $i$ tris grupes: mokinius, kurie niekada ar tik karta per mènesi rūkè ar vartojo svaigiuosius gèrimus; keletą kartų per mėnesi rūkančius ar vartojančius svaigiuosius gèrimus ir keletą kartų per savaitę 
ar kasdien rūkančius ir vartojančius svaigiuosius gèrimus mokinius.

Mokiniu i̇sitraukimas į i̇vairiu formų prievartą buvo nustatytas taikant klausimų bloką, sudarytą iš 12 klausimu (šeši klausimai buvo skirti nustatyti priekabiavimui, kiti šeši - viktimizacijai). Ivairioms viktimizacijos formoms išaiškinti buvo pateikiami skirtingi klausimai, pvz., „,Kiek kartu per pastaruosius du ménesius apie tave buvo kalbama netiesa siekiant, kad kiti moksleiviai su tavimi nedraugautu?".. Atsakymų variantai buvo išdèstyti dažnejjimo tvarka: nè karto, kartą per mènesị, kartą per savaitę, keletą kartų per savaitę. Mokiniai buvo suskirstyti i priekabiautojų, aukų ir priekabiautojų / auku grupes pagal įvairias prievartos formas (erzinimo, verbalines, santykiu ir fizines), jei pripažino, kad prie ju priekabiaujama arba patys priekabiauja kartą per savaitę ir dažniau. Pavyzdžiui, erzinimo aukų grupei priskirti mokiniai, erzinami kartą per savaitę ir dažniau, tačiau patys taip niekada nesielgiantys arba taip besielgiantys rečiau negu kartą per savaitę. Fizinès prievartos grupei buvo priskiriami mokiniai, kurie pripažino, kad patys priekabiauja (pastumia, paliečia ir pan., norèdami kitą pažeminti) kartą per savaitę ir dažniau, tačiau niekada netampa tokio elgesio aukomis arba tokị elgesị patiria rečiau negu kartą per savaitę. Aukų ir priekabiautoju grupei priskirti mokiniai, kartą per savaitę tampantys ívairiu prievartos formų aukomis, tačiau ir patys kartą per savaitę ar dažniau prie kitu priekabiaujantys.

Mokiniu mokymosi motyvacija buvo tiriama pateikiant 10 teiginių skalę (pvz., Aš mokausi todèl, kad man patinka sužinoti ka nors naujo). Kiekvieną teigini mokiniai turejo įvertinti pažymėdami vieną iš penkių atsakymo variantų: nuo „labai svarbu“ iki „visai nesvarbu“. Pagal gautą bendrą visų tiriamuju balų sumos vidurkį tiriamuosius suskirsteme i dvi grupes: mokinius, kuriems būdinga aukštesnè ir žemesnè mokymosi motyvacija.

Požiūris į mokyklą buvo tiriamas pateikiant keletą klausimų apie tai, ar jiems patinka mokykloje, kaip juos, kaip mokinius, vertina mokytojai.

Tyrimo eiga. Apklausa buvo atliekama pamokų metu, prieš tai susitarus su mokyklos direktoriumi ir pasirenkamų klasių mokytojais. Laikantis tiriamuju informavimo ir savanoriškumo principu, mokiniams buvo paaiškintas tyrimo tikslas, o nenorintys gali atsisakyti joje dalyvauti. Taip pat mokiniai buvo informuojami apie tyrimo anonimiškumą.

Statistinė analizè. Statistinè tyrimo duomenu analizé atlikta naudojant programų paketą SPSS
13 for Windows. Vertinant skirtumą tarp kelių nepriklausomų imčių, buvo taikomas neparametrinis Kruscal ir Wallis testas, o vertinant skirtumus tarp dviejų imčiu - chi kvadrato kriterijus. Skirtumo patikimumas laikytas reikšmingu, kai $\mathrm{p}<0,05$.

\section{REZULTATAI}

Tyrimas atskleide, kad iš viso pasirinktos sporto šakos pratybas lanko $26,8 \%$ mokinių (mergaičiu $27,1 \%$, berniuku $-26,3 \%$ ). Laisvalaikiu fiziškai aktyvūs buvo $66,1 \%$ mokinių (64,2\% mergaičių ir $68,4 \%$ berniuku). Fiziškai pasyvūs sudare tik 7,2\% respondentu ( $8,7 \%$ mergaičiu ir $5,3 \%$ berniuku).

Skirtingo fizinio aktyvumo mokiniai skiriasi socialinès integracijos lygiu (1 lent.). Kur kas geresni socialinès integracijos rodikliai yra laisvalaikiu fiziškai aktyvių mokinių, tiek lyginant juos su sportuojančiais $\left(\chi^{2}=11,68 ; 1.1 .=1 ; p<0,001\right)$, tiek su fiziškai pasyviais $\left(\chi^{2}=14,05 ; 1.1 .=1 ; p<0,001\right)$ bendraamžiais. Nors tarp pastarujų dvieju grupių statistiškai reikšmingo skirtumo nenustatyta, tačiau matyti tendencija, kad daugiausia fiziškai pasyvių mokinių pateko i̇ žemesnès socialinès integracijos grupę. Tyrimo duomenimis, fizinis aktyvumas nebuvo susijęs su socialine integracija tarp mergaičių, tačiau fizinis aktyvumas prognozavo berniukų socialinę integraciją: $82,8 \%$ laisvalaikiu fiziškai aktyvių berniukų, lyginant su $64,2 \%$ sportuojančiais $\left(\chi^{2}=15,7 ; 1.1 .=1 ; p<0,01\right)$ ir $40,9 \%$ fiziškai pasyviais bendraamžiais $\left(\chi^{2}=22,25\right.$; 1.1. $=1 ; p<0,001)$, pateko í aukštesnès socialinès integracijos grupę. Be to, fiziškai pasyvių šis rodiklis buvo daug prastesnis nei sportuojančiu $\left(\chi^{2}=4,16 ; 1.1 .=1 ; p<0,05\right)$.

Visgi tyrimo duomenys neatskleidè kokių nors ryškesnių mokinių fizinio aktyvumo ir savigarbos sąsaju (1 lent.). Galima kalbèti tik apie kai kurias tendencijas: antai tarp mergaičiu žemiausios savigarbos, lyginant su kitomis fizinio aktyvumo grupemis, yra fiziškai pasyvios, o tarp berniuku priešingai - sportuojantys.

Mažiausiai rūkančių tarp laisvalaikiu fiziškai aktyvių mokiniu $(74,1 \%)$, daugiausia - tarp fiziškai pasyvių $(62,1 \%)$ (2 lent.). Kita vertus, statistiškai reikšmingas skirtumas aptiktas tarp sportuojančių ir laisvalaikiu fiziškai aktyviu mokiniu $\left(\chi^{2}=7,25 ; 1.1 .=2 ; p<0,05\right)$. Vertinant mergaičių rūkymo duomenis, nustatyta tokia tendencija: daugiau per pastaruosius metus visai nerūkiusių ar tik po kartą per mènesi tai dariusių buvo tarp sportuojančių ir laisvalaikiu fiziškai aktyviu mergaičiu (atitinkamai 77,0 ir 77,2\%). 


\begin{tabular}{|c|c|c|c|c|c|c|c|c|c|c|}
\hline \multirow{2}{*}{$\begin{array}{l}\text { Tocialinès } \\
\text { integracijos ir } \\
\text { savigarbos lygis }\end{array}$} & \multicolumn{3}{|c|}{ Mergaitès } & \multicolumn{3}{|c|}{ Berniukai } & \multicolumn{3}{|c|}{ Iš viso } & \multirow{6}{*}{$\begin{array}{l}1 \text { lentelè. Skir- } \\
\text { tingo fizinio ak- } \\
\text { tyvumo moks- } \\
\text { leivių socialinės } \\
\text { integracijos ir } \\
\text { savigarbos duo- } \\
\text { menys (\%) }\end{array}$} \\
\hline & SP & LFA & FP & SP & LFA & FP & SP & LFA & FP & \\
\hline $\begin{array}{l}\text { Socialine izoliacijal } \\
\text { integracija }\end{array}$ & $\mathrm{n}=137$ & $\mathrm{n}=322$ & $\mathrm{n}=44$ & $\mathrm{n}=109$ & $\mathrm{n}=285$ & $\mathrm{n}=22$ & $\mathrm{n}=246$ & $n=607$ & $\mathrm{n}=66$ & \\
\hline $\begin{array}{l}\text { Aukštesnès socialinès } \\
\text { integracijos }\end{array}$ & 69,3 & 74,4 & 65,9 & 64,2 & 82,8 & 40,9 & 67,1 & 78,3 & 57,6 & \\
\hline \multirow{2}{*}{$\begin{array}{l}\text { Žemesnès socialinès } \\
\text { integracijos }\end{array}$} & 30,7 & 25,6 & 34,1 & 35,8 & 17,2 & 59,1 & 32,9 & 21,7 & 42,4 & \\
\hline & & & & \multicolumn{3}{|c|}{$\chi^{2}=30,2 ; 1.1 .=2 ; p<0,001$} & \multicolumn{3}{|c|}{$\chi^{2}=20,96 ; 1.1 .=2 ; p<0,001$} & \\
\hline Savigarba & $\mathrm{n}=136$ & $\mathrm{n}=324$ & $\mathrm{n}=44$ & $\mathrm{n}=108$ & $\mathrm{n}=278$ & $\mathrm{n}=21$ & $\mathrm{n}=244$ & $\mathrm{n}=602$ & $\mathrm{n}=65$ & sportuojantys; \\
\hline Aukštesnès savigarbos & 44,9 & 45,7 & 38,6 & 38,9 & 46,8 & 47,6 & 42,2 & 46,0 & 41,5 & $\begin{array}{l}\text { LFA - laisva- } \\
\text { laikiu fiziškai }\end{array}$ \\
\hline Žemesnès savigarbos & 55,1 & 54,3 & 61,4 & 61,1 & 53,2 & 52,4 & 57,8 & 54,0 & 58,5 & $\begin{array}{l}\text { aktyvūs; FP - } \\
\text { fiziškai pasyvūs. }\end{array}$ \\
\hline
\end{tabular}

\begin{tabular}{|c|c|c|c|c|c|c|c|c|c|c|}
\hline \multirow{2}{*}{ Žalingieji ịpročiaI } & \multicolumn{3}{|c|}{ Mergaitès } & \multicolumn{3}{|c|}{ Berniukai } & \multicolumn{3}{|c|}{ Iš viso } & \multirow{11}{*}{$\begin{array}{l}2 \text { lentelè. Skir- } \\
\text { tingo fizinio ak- } \\
\text { tyvumo moks- } \\
\text { leivių rūkymo } \\
\text { ir svaigiųjų gè- } \\
\text { rimų vartojimo } \\
\text { duomenys (\%) }\end{array}$} \\
\hline & SP & LFA & FP & SP & LFA & FP & SP & LFA & FP & \\
\hline Rūkymas & $\mathrm{n}=135$ & $\mathrm{n}=320$ & $\mathrm{n}=44$ & $\mathrm{n}=109$ & $\mathrm{n}=281$ & $\mathrm{n}=22$ & $\mathrm{n}=244$ & $\mathrm{n}=601$ & $n=66$ & \\
\hline $\begin{array}{l}\text { Niekada ar kartą per } \\
\text { mèn. }\end{array}$ & 77,0 & 77,2 & 63,6 & 64,2 & 70,8 & 59,1 & 71,3 & 74,1 & 62,1 & \\
\hline $\begin{array}{l}\text { Keletą kartų per } \\
\text { mèn. }\end{array}$ & 6,7 & 12,2 & 13,6 & 8,3 & 10,0 & 13,6 & 7,4 & 11,2 & 13,6 & \\
\hline $\begin{array}{l}\text { Keletą kartų per } \\
\text { savaitę }\end{array}$ & 16,3 & 10,6 & 22,7 & 27,5 & 19,2 & 27,3 & 21,3 & 14,7 & 24,3 & \\
\hline & & & & & & & $\chi^{2}=10,9$ & $3 ; 1.1 .=4$ & $<0,03$ & \\
\hline $\begin{array}{l}\text { Svaigiuju gérimu } \\
\text { vartojimas }\end{array}$ & $\mathrm{n}=134$ & $\mathrm{n}=322$ & $\mathrm{n}=44$ & $\mathrm{n}=109$ & $\mathrm{n}=280$ & $\mathrm{n}=22$ & $\mathrm{n}=243$ & $\mathrm{n}=602$ & $\mathrm{n}=66$ & \\
\hline $\begin{array}{l}\text { Niekada ar kartą per } \\
\text { mėn. }\end{array}$ & 55,2 & 58,7 & 50,0 & 55,0 & 57,5 & 36,4 & 55,1 & 58,0 & 45,5 & \\
\hline $\begin{array}{l}\text { Keletą kartų per } \\
\text { mėn. }\end{array}$ & 42,5 & 40,1 & 47,7 & 37,6 & 36,4 & 63,6 & 40,3 & 38,5 & 53,0 & \\
\hline $\begin{array}{l}\text { Keletą kartų per } \\
\text { savaitę }\end{array}$ & 2,3 & 1,2 & 2,3 & 7,4 & 6,1 & 0,0 & 4,6 & 3,5 & 1,5 & \\
\hline
\end{tabular}

Tarp fiziškai pasyvių bendraamžių rūkymo paplitimas mažesnis $(63,6 \%)$. Vertinant rūkančius berniukus, mažiausiai tokių asmenų rasta tarp laisvalaikiu fiziškai aktyvių moksleivių, o tarp sportuojančių ir fiziškai pasyvių bendraamžių rūkančiujų paplitimas yra panašus.

Vertinant mokinių duomenis pagal svaigiuju gérimų vartojima, patikimo skirtumo nenustatyta (2 lent.). Čia vèlgi galima kalbèti tik apie tendencijas, rodančias, kad daugiausia vartojančių svaigiuosius gèrimus yra tarp fiziškai pasyvių mokinių, lyginant juos su sportuojančiais ir laisvalaikiu fiziškai aktyviais. Šios tendencijos statistiškai reikšmingas skirtumas pastebimas tarp skirtingo fizinio aktyvumo berniuku, t. y. tarp fiziškai pasyviu berniukų kur kas daugiau vartojančių svaigiuosius gèrimus nei tarp fiziškai aktyvesnių $\left(\chi^{2}=6,89\right.$; 1.1. $=2 ; \mathrm{p}<0,05)$.
Tiriant priekabiavimo paplitimą nustatyta, kad iš viso i priekabiavimą buvo isitraukę 657 (56,5\%) mokiniai. $148(12,7 \%)$ buvo priskirti auku, o 189 (16,3\%) - priekabiautojų grupėms. Vertinant bendruosius i priekabiavimą isitraukusių respondentų duomenis (3 lent.) pastebėta, kad tokių daugiausia tarp laisvalaikiu fiziškai aktyvių mokiniu (61,0\%), o tarp sportuojančiu (55,3\%) ir fiziškai pasyvių (45,5\%) ju kur kas mažiau. Analogiška tendencija nustatyta ir tarp merginų. Tarp skirtingo fizinio aktyvumo berniuku tokiu mokinių pasiskirstymas yra beveik vienodas.

Apklausos duomenimis (3 lent.), dažniau prie kitų mokinių mokykloje priekabiauja laisvalaikiu fiziškai aktyvūs $(18,8 \%)$ nei sportuojantys $(13,0 \%)$ $\left(\chi^{2}=4,11 ; 1.1 .=1 ; \mathrm{p}<0,05\right)$ ir fiziškai pasyvūs $(7,6 \%)$ bendraamžiai $\left(\chi^{2}=5,14 ; 1.1 .=1 ; \mathrm{p}<0,05\right)$. Analogiška tendencija išlieka tarp skirtingo fizinio 


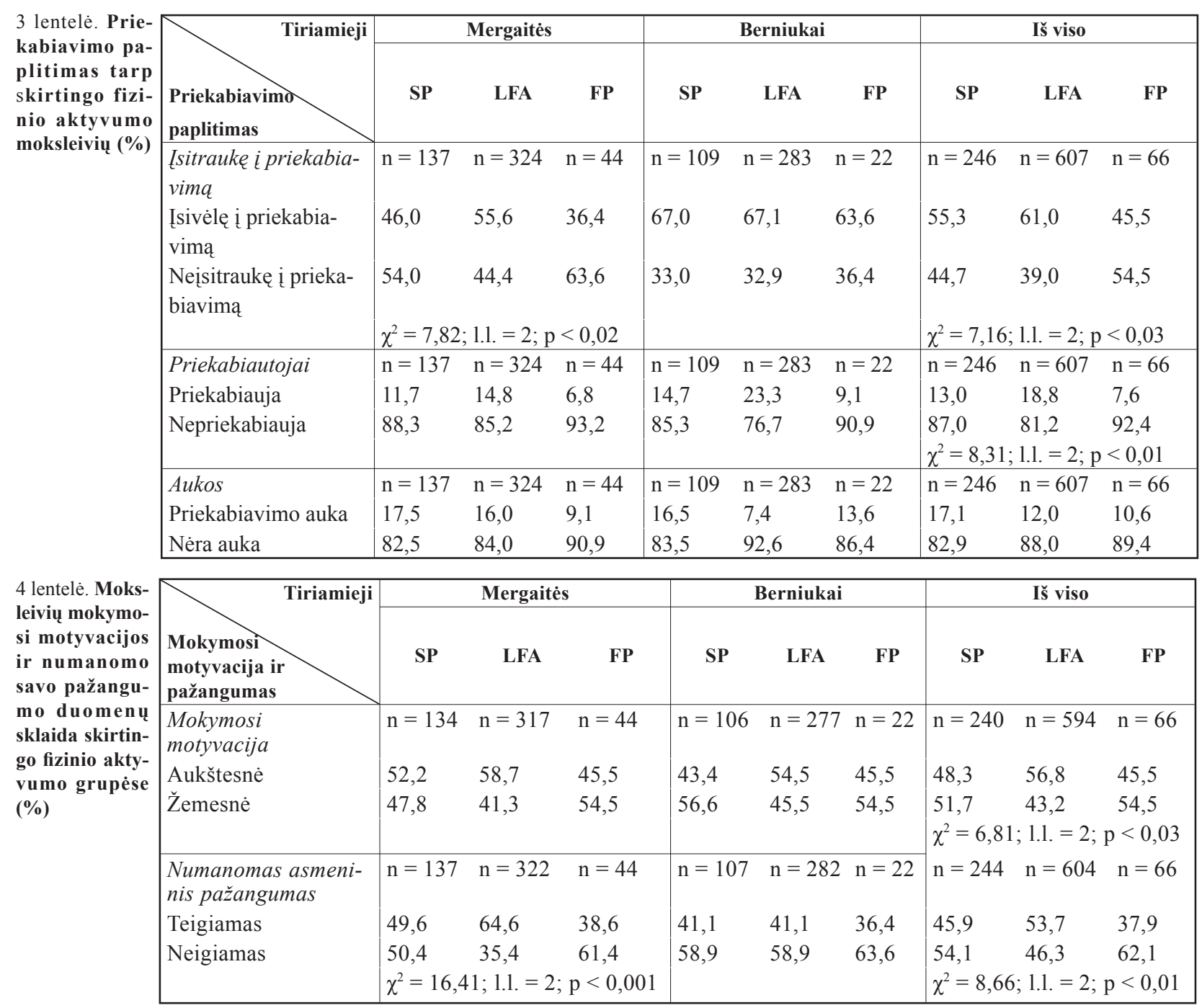

aktyvumo mergaičių ir berniukų, nors tas skirtumas nèra statistiškai reikšmingas.

Viktimizacija nebuvo statistiškai reikšmingai susijusi su fiziniu aktyvumu, nors nustatyta tendencija, kad berniuku grupejje mažiausiai auku yra tarp laisvalaikiu fiziškai aktyvių mokinių. Tarp mergaičių mažiausiai aukų yra fiziškai pasyvių grupejje.

Nustatytas skirtumas tarp skirtingo fizinio aktyvumo mokinių mokymosi motyvacijos (4 lent.), t. y. daugiau laisvalaikiu fiziškai aktyviu mokiniu pateko į aukštesnès mokymosi motyvacijos grupę. Tarp skirtingo fizinio aktyvumo mergaičiu pastebimos tendencijos, kad daugiau fiziškai pasyvių pateko į žemesnès mokymosi motyvacijos grupę. Vertinant berniukų mokymosi motyvacijos duomenis, nustatytas ir statistiškai reikšmingas skirtumas tarp sportuojančių ir laisvalaikiu fiziškai aktyvių mokiniu $\left(\chi^{2}=3,74 ; 1.1 .=1 ; p<0,05\right)$.

Tyrimas neatskleidè skirtumo vertinant mokinių požiūrị i mokyklą, t. y. daugumai respondentu mokykla šiek tiek ar netgi labai patinka. Kita vertus, analizuojant mokinių nuomonę apie tai, kaip juos vertina mokytojai, išryškejjo skirtumas, t. y. laisvalaikiu fiziškai aktyvūs dažniau nei sportuojantys $\left(\chi^{2}=4,18 ; 1.1 .=1 ; p<0,04\right)$ ir fiziškai pasyvūs $\left(\chi^{2}=5,93 ; 1.1 .=1 ; p<0,01\right)$ galvoja, kad mokytojai juos vertina geriau. Šiuo aspektu prasčiausiai save vertino fiziškai pasyvūs mokiniai. Skirtumas dar akivaizdesnis vertinant mergaičiu duomenis. Laisvalaikiu fiziškai aktyvių mergaičiu nuomone, mokytojai jas kur kas geriau vertina nei sportuojančias $\left(\chi^{2}=10,99 ; 1.1 .=1 ; p<0,01\right)$ ir fiziškai pasyvias $\left(\chi^{2}=11,01 ; 1.1 .=1 ; p<0,01\right)$. Tuo tarpu berniukų grupejje statistiškai reikšmingo skirtumo nenustatyta.

\section{REZULTATŲ APTARIMAS}

Šiuo tyrimu siekta atskleisti mokinių sportavimo ir fizinio aktyvumo laisvalaikiu sąsajas su psichosocialiniais, elgesio ir mokyklos veiksniais. Nors literatūroje yra duomenų, kad aukštesnis socialinès integracijos lygis susijęs su didesne 
savigarba (Batutis, Kardelis, 2002), taip pat egzistuoja sąsajos tarp sportavimo ir savigarbos, tačiau mūsų tyrimas nei vienos, nei antros prielaidos nepatvirtino. Apklausos duomenimis, nèra skirtumo vertinant sportuojančiuc, laisvalaikiu fiziškai aktyvių ir fiziškai pasyvių mokinių savigarbą. Pastebèta netgi priešinga tendencija, t. y. būtent sportuojančiu berniukų savigarba žemesnè. Nagrinèjant, kodèl mūsų tyrimo duomenys nesutampa su kitų tyrejų duomenimis, reikia prisiminti, kad sportinè veikla dažnai vertinama palankiai, kalbant apie savigarbos ugdymą, nes sportuojantys gali geriau pažinti save, gauti grị̌tamają informaciją apie savo gebejjimų tobulèjimą bendraujant su bendraamžiais ir suaugusiaisiais, ypač treneriu. Tačiau sportuojant galima patirti ir neigiamą kitu bendraamžių, suaugusiujų įtaką. D. M. Hansen, R. W. Larson ir J. B. Dworkin (2003) pažymi, kad tiek teigiama, tiek neigiamą itaka galima sieti su varžybine sporto prigimtimi, kuri gali skatinti konkurenciją tarp bendraamžių. Dèl šios priežasties bendravimas gali igauti ir neigiamą prasmę. Be to, svarbu, koks paties trenerio bendravimas su sportininkais, kokiomis vertybemis jis remiasi, kiek suteikia auklètiniams autonomijos, priimant asmeninius sprendimus. Taip pat reikia atsižvelgti i sportinę patirtị ir sporto šakos pobūdị. Čia, mūsų nuomone, kur kas svarbesnis pirmasis aspektas, nes būtent didejjant patirčiai igyjamas didesnis sportinis meistriškumas, kartu dideja ir konkurencija. Šiuo aspektu išryškejja vienas mūsų tyrimo trūkumas. Sportuojančiu grupei priskyrėme tuos mokinius, kurie sporto šakos pratybas lanko ne mažiau kaip pusę metų. Taigi jų grupei priklausè ir tie, kurių sportinis stažas pakankamai ilgas, ir tie, kurių stažas tik pusè metų. Todèl negalima atmesti prielaidos, kad mokinių sportinis stažas buvo pakankamai trumpas, ir tai gali būti viena iš priežasčių, kodèl jų savigarba nèra aukštesnè nei fiziškai pasyvių bendraamžių.

Vertinant žalingus ipročius nustatyta, kad rūkymas labiau paplitęs tarp fiziškai pasyvių mokinių. Nors vertinant svaigiuju gėrimų vartojimą statistiškai reikšmingo skirtumo tarp grupiu nenustatyta, visgi verta atkreipti dèmesi i kai kurias tendencijas. Niekada ar tik karta per ménesi vartojusių svaigiuosius gèrimus daugiausia buvo tarp laisvalaikiu fiziškai aktyvių, o keletą kartu per savaitę vartojančiu (nors tokių asmenų skaičius tarp visų tyrimo dalyvių nesiekia nẻ dešimties procentų) daugiausia rasta tarp sportuojančiujų. Tokia tendencija nestebina, nes ir kitų tyrimų duomenys rodo, kad sportuojantieji dažniau vartoja svai- giuosius gèrimus (Barber et al., 2003; Harrison, Narayan, 2003).

Tyrimo metu nustatyti dažnesni priekabiavimo atvejai nei kitose šią temą nagrinèjusiose studijose (Scheithauer et al., 2006; Yang et al., 2006). Beje, toks elgesys susijęs su mokinių fiziniu aktyvumu, t. y. būdingesnis tarp laisvalaikiu fiziškai aktyviu moksleivių, o tarp sportuojančių ir fiziškai pasyviu paplitęs mažiau. Analogiškos tendencijos matomos tiek tarp mergaičių, tiek tarp berniukų, o tarp pastarujų apskritai daugiau taip besielgiančių. Analogišką skirtumą lyties aspektu yra nustatę ir kiti tyrèjai. Jų duomenimis, problemiškas elgesys būdingesnis vaikinams ir nesportuojantiems moksleiviams (Rhea, Lantz, 2004; Scheithauer et al.; 2006, Yang et al., 2006). Nustatytos tendencijos rodo, kad sportuojantys asmenys nebūtinai yra agresyvesni. Čia galima pacituoti J. P. McHale (2005) ir bendraautoriu kūno kultūros mokytojų apklausos duomenis - jie sportuojančius mokinius, lygindami su nesportuojančiaisiais, apibūdina kaip mažiau agresyvius. Kita vertus, kai kurie autoriai (Burton, Marshall, 2005), lygindami probleminio elgesio raiškos sąsajas su dalyvavimu popamokinèje veikloje, vis tik daro išvadą, kad sporto šakos pratybų lankymas nebūtinai apsaugo mokinius nuo įsitraukimo į delikventišką elgesi. Keliama prielaida, kad sportuojančius mokinius nuo neigiamo elgesio atitraukia tokie motyvai kaip baimè dèl blogo elgesio būti pašalintiems iš sporto klubo. Be to, kai kuriais tyrimais nustatyta, kad ne pats dalyvavimas sportinèje veikloje, o būtent didesnis sportinis identitetas yra susijęs su agresijos raiška tarp paaugliu (Miller et al., 2006), todèl tolesniais tyrimais vertètu ji nustatyti.

Tiriant taip pat nustatytos mokiniu mokymosi motyvacijos ir fizinio aktyvumo sąsajos. Mūsų duomenimis, laisvalaikiu fiziškai aktyvių mokinių mokymosi motyvacija aukštesnè nei sportuojančiu ir fiziškai pasyvių. Beje, analogiškas skirtumas nustatytas tiek mergaičiu, tiek berniukų grupèse. Analogiškos tendencijos išryškejja ir vertinant mokiniu nuomonę apie tai, kaip juos pačius vertina klasès auklètojas. Šiuo aspektu geriausiai save vertina laisvalaikiu fiziškai aktyvūs mokiniai, kiek prasčiau sportuojantys, o fiziškai pasyvūs - prasčiausiai. Analogiškas skirtumas matomas ir mergaičiu grupėse. Mokinių požiūris į mokyklą fizinio aktyvumo grupèse nesiskiria. Tai leidžia teigti, kad rastas skirtumas fizinio aktyvumo grupèse vienais su mokykla ir mokymusi susijusiais aspektais nebūtinai išlieka ir kitais. Kai kurie tyrèjai yra pastebejję, kad sportuojančius mokinius geriau vertina mokytojai (Fletcher et al., 2003), kur kas geriau jie jaučiasi 
ir mokykloje (Barber et al., 2003). Ir visgi fizinis aktyvumas nèra susijęs su geresniais mokymosi pasiekimais. Palankesnį mokytojų vertinimą lemia didesnis jų aktyvumas klasèje, t. y. bendravimas tiek su kitais mokiniais, tiek su mokytoju.

Apie mokinių bendravimą su kitais leidžia spręsti socialinès integracijos duomenys, kurie tyrimo metu atskleide, kad tiek sportuojantys, tiek laisvalaikiu fiziškai aktyvūs mokiniai yra aukštesnio integracijos lygio nei fiziškai pasyvūs bendraamžiai. Visgi reikia pabrèžti, kad šis skirtumas būdingesnis berniukų grupèse, kur ypač išsiskyre fiziškai pasyvūs mokiniai savo žemesniais socialinès integracijos ir izoliacijos balais. Tuo tarpu skirtingo fizinio aktyvumo mergaitès pagal ši rodikli nesiskiria. Ši skirtumą pagal lytị galbūt lemia tai, kad fiziškai pasyvios mergaitès labiau nei berniukai dalyvauja kitokio pobūdžio (nesusijusio su sportavimu) organizuotoje popamokinejje veikloje, kuria skatinamas bendravimas su kitais. Šią prielaidą patvirtina S. C. Duncan, T. E. Duncan, L. A. Stryker ir N. Chaumeton (2002) 10-14 metų moksleiviu apklausos duomenys. Kiti tyrejjai (Harrison, Narayan, 2003) taip pat yra pastebeję, kad mokiniams, nedalyvaujantiems jokioje popamokinèje veikloje (galima daryti prielaida, kad tarp jų daugiau būna ir fiziškai pasyvių), mažiau patinka mokykla nei sportuojantiems ir laisvalaikiu fiziškai aktyviems bendraamžiams. Kita vertus, mūsų apklausos metu nebuvo prašoma nurodyti dalyvavimo popamoki- nėje veikloje rūšies, todèl išsakytą prielaidą reikètų tikrinti tolesniais tyrimais.

\section{IŠVADOS}

1. Aukštesnès socialinès integracijos yra laisvalaikiu fiziškai aktyvūs mokiniai, lyginant juos su sportuojančiais ir fiziškai pasyviais bendraamžiais. Analogiškas skirtumas nustatytas ir tarp berniukų, tačiau neužfiksuotas tarp mergaičių. Nerasta skirtumo tarp sportuojančiu, laisvalaikiu fiziškai aktyvių ir pasyvių mokinių savigarbos.

2. Rūkymas labiau paplitęs tarp fiziškai pasyvių mokinių. Sportuojantys mokiniai dažniau rūko nei laisvalaikiu fiziškai aktyvūs bendraamžiai. Skirtumas tarp skirtingo fizinio aktyvumo moksleiviu pagal svaigiujų gėrimų vartojimą nenustatytas.

3. Fiziškai aktyvūs mokiniai dažniau isitraukia ị priekabiavimą nei sportuojantys ir fiziškai pasyvūs bendraamžiai. Jiems statistiškai reikšmingai būdingesnis priekabiavimas, tačiau reikšmingų sąsajų tarp viktimizacijos ir fizinio aktyvumo nerasta.

4. Laisvalaikiu fiziškai aktyvių mokinių mokymosi motyvacija aukštesnè ir sportuojančių bei fiziškai pasyvių. Laisvalaikiu fiziškai aktyvūs mokiniai yra palankesnès nuomonès apie save, kaip apie moksleivi, nei sportuojantys ar fiziškai pasyvūs bendraamžiai. Analogiška tendencija nustatyta ir tarp mergaičiu, tačiau nebūdinga berniukams.

\section{LITERATŪRA}

Barber, B. L., Stone, M., Hunt, J. (2003). Extracurricular activities and adolescent development. Journal of Social Issues, 59 (4), 865-889.

Batutis, O., Kardelis, K. (2002). Moksleivių socialinès izoliacijos, integracijos ir savigarbos sąsaja su fiziniu aktyvumu. Ugdymas. Kūno kultūra. Sportas, 2 (43), 10-16.

Burton, J. M., Marshall, L. A. (2005). Protective factors for youth considered at risk of criminal behaviour: Does participation in extracurricular activities help? Criminal Behaviour and Mental Health, 15, 46-64.

Duncan, S. C., Duncan, T. E., Strycker, L. A., Chaumeton, N. (2002). Relations between youth antisocial and prosocial activities. Journal of Behavioral Medicine, 25 (5), 425-438.

Fletcher, A. C., Nickerson, P., Wright, K. L. (2003). Structured leisure activities in middle childhood: Links to well-being. Journal of Community Psychology, 31 (6), 641-659.

Grinienè, E. (1998). Sportuojančių moksleivių rūpinimasis sveikata. Sporto mokslas, 4 (13), 38-41.

Hansen, D. M., Larson, R. W., Dworkin, J. B. (2003). What adolescents learn in organized youth activities: A survey of self-reported developmental experiences. Journal of Research on Adolescence, 13 (1), 25-55.

Harrison, P. A., Narayan, G. (2003). Differences in behavior, psychological factors, and environmental factors associated with participation in school sports and other activities in adolescence. Journal of School Health, 73 (3), 113-120.

Hayes, S. D., Crocker, P. R., Kowalski, K. C. (1999). Gender differences in physical self-perceptions, global selfesteem and physical activity: Evaluation of the physical self-perception profile model. Journal of Sport Behavior, 99 (22), $1-14$.

Kardelis, K., Misevičienė, J., Šaferis, V. (2001). Studentu gyvensena ir požiūris ị sveikatos stiprinimą. Ugdymas. Kūno kultūra. Sportas, 2 (39), 22-26.

Kirkcaldy, B. D., Shepard, R. J., Siefen, R. G. (2002). The relationship between physical activity and self-image and problem behaviour among adolescents. Social Psychiatry and Psychiatric Epidemiology, 37 (11), 544-550.

McHale, J. P., Vinden, P. G., Bush, L. et al. (2005). Patterns of personal and adjustment among sport-involved and noninvolved urban middle-school children. Sociology of Sport Journal, 22 (2), 119-137.

Miller, K. E., Melnick, M. J., Farrell, M. P., Sabo, D. F., Barnes, G. M. (2006). Jocks, gender, binge drinking, and adolescent violence. Journal of Interpersonal Violence, 21, 105-120.

Pate, R. R., Trost, S. G., Levin, S., Dowda, M. (2000). Sports participation and health-related behaviours among 
US youth. Archives of Pediatrics \& Adolescent Medicine, 154 (9), 904-1000.

Petkevičienė, J., Kardelis, K., Misevičienè, I., Petrauskas, D. (2002). Kauno aukštujų mokyklų studentų fizinio aktyvumo, žalingų ipročių ir studijų krypties sąsaja. Ugdymas. Küno kultūra. Sportas, 4 (45), 77-83.

Rhea, D. J., Lantz, C. D. (2004). Violent, delinquent, and aggressive behaviors of rural high school athletes and nonathletes. Physical Educator, 61 (4), 170-176.

Rosenberg, M. (1989). Society and the Adolescent SelfImage. Revised edition. Middletown, CT: Wesleyan University Press.
Scheithauer, H., Hayer, T., Petermann, F., Jugert, G. (2006). Physical, verbal and relational forms of bullying among gernab students: Age trends, gender differencies, and cCorrelates. Aggressive Behavior, 32, 261-275.

Zaborskis, A., Žemaitienè, N., Šumskas, L., Diržytè, A. (1996). Moksleiviu gyvenimo būdas ir sveikata. Vilnius.

Yang, S. J., Kim, J. M., Kim, S. W., Shin, I. S., Yoon, J. S. (2006). Bullying and victimization behaviors in boys and girls at South Korean primary schools. Journal of the American Academy of Child And Adolescent Psychiatry, 45, 69-77.

\title{
LINKS BETWEEN PUPILS' SPORTS AND PHYSICAL ACTIVITIES IN THEIR LEISURE TIME AND PSYCHOSOCIAL, BEHAVIORAL AND SCHOOL FACTORS
}

\author{
Saulius Šukys, Rasa Jankauskienė \\ Lithuanian Academy of Physical Education, Kaunas, Lithuania
}

\begin{abstract}
There is not much research considering the singleness of physical activity when dealing with the psychosocial and behavioral problems of pupils' physical activity. Thus the aim of the research is to reveal the links between pupils' sports and physical activities in their leisure time and their psychosocial, behavioral and school factors.

The questionnaire method was applied to collect the data about pupils' social integration, isolation and selfrespect (psychosocial factors), harmful habits and harassment (behavioral factors) and their learning motivation and attitudes towards school (factors linked with school). The sample consisted of the representative group of 1162 pupils from the sixth, eighth and eleventh grades (534 boys and 628 girls). They were randomly selected from Kaunas city schools. As part of the research participants did not answer the questions about their physical activity nor did it correctly, the final sample decreased up to 919 persons.

Research data showed that pupils who were physically active in their leisure time manifested higher indicators of social integration compared to their peers who were engaged in sports or who were physically passive. Analogical differences were characteristic of boys, but they were not established among girls. No selfrespect differences were established among pupils who were engaged in sports and who were physically active or passive in their leisure time.

Smoking is typical of physically passive pupils. Pupils who were engaged in sports were greater smokers compared to their peers who were physically active in their leisure activities. Research established a tendency that both boys and girls physically passive in their leisure time were smoking more often compared to their more physically active contemporaries. However, no differences in alcohol abuse were established among pupils with different levels of physical activity.

Physically active pupils were more inclined to harassment than their peers who went in for sports or were physically passive. Statistically harassment was more characteristic of them, though no significant links were found between victimization and physical activity.

Learning motivation of physically active pupils was higher than those who went in for sports or who were physically passive. Analogically learning motivation of physically active boys was higher than of pupils who were engaged in sports. Research data revealed that physically active pupils were of higher opinion about themselves as learners compared to pupils who went in for sports and who were physically passive. Analogical tendency was established among girls, but it was not characteristic of boys.
\end{abstract}

Keywords: physical activity of pupils, social integration and isolation, self-respect, manifestation of harmful habits and harassment, learning motivation, attitude towards school.

Gauta 2007 m. gegužès 2 d.

Received on May 2, 2007

Priimta $2007 \mathrm{~m}$. rugsẻjo $19 \mathrm{~d}$.

Accepted on September 19, 2007
Saulius Šukys

Lietuvos kūno kultūros akademija

(Lithuanian Academy of Physical Education)

Sporto g. 6, LT-44221 Kaunas

Lietuva (Lithuania)

Tel +370 37302637

E-mailsml.saulius@mail.lt 